\title{
The Future of Welfare State Politics
}

\author{
Philipp Rehm* \\ Department of Political Science, Ohio State University, 154 N. Oval Mall, Columbus, OH 43210, USA \\ ${ }^{\star}$ Corresponding author. Email: rehm.16@osu.edu
}

(Received 21 May 2018; accepted 11 July 2018; first published online 12 November 2019)

\begin{abstract}
This essay argues that several ongoing and future developments are likely to undermine the broad public support welfare states historically and currently enjoy. These developments-skill-biased technological change, privatization of pensions, higher rates of assortative mating, and the information revolutioncan be expected to increase risk inequality, the predictability of risk, income and wealth inequality, and the overlap between income and risk. As a result, a plausible prediction is that intense polarization about social policy programs will replace their current broad appeal, pitting an increasing share of people with no jobs or poor jobs and little upward mobility against an increasing share of people with few incentives to support mandatory risk pooling because they can self-insure.
\end{abstract}

Keywords: Comparative Politics; Industrialized Countries; Social Policy; Comparative Political Economy; Public Policy

\section{Introduction}

In the past, welfare states enjoyed relatively broad and high public support, and differences in opinion were a matter of degree. Despite the challenges outlined in the introduction, even today most citizens embrace the idea that governments should provide social protection. For example, David Rueda's $(2005,2007)$ influential work shows that labor market insiders and outsiders hold different policy attitudes, but their disagreements seem relatively modest (Rueda 2005, fig. 2). In this essay, I argue that the welfare state politics of the future will be qualitatively different. Rather than struggling over "more or less" spending, citizens will be increasingly riven over the question whether certain policies should be provided by governments at all ("whether or not").

I argue that social policy arrangements will come under pressure both from below and from above. At the bottom of the income-risk distribution, an increasingly visible and sizeable group of low-skilled workers with little upward mobility will emerge ("permanent outsiders"). At the top, it will be increasingly unattractive for the well-off to pool risks with the rest of society ("insiders that want out"), making it increasingly difficult to maintain broad support for mandatory social insurance programs that are so typical of rich democracies. This will significantly and qualitatively alter the politics of social solidarity.

\section{The argument}

Social policy programs perform three main functions, which have been described with the metaphors of the hammock, the safety net or piggy bank, and the trampoline: they redistribute; they insure by providing income maintenance while people are unavailable to work (accident, sickness, disability, unemployment, old-age, maternity, etc.) (Iversen and Soskice 2001; Iversen 2005); and they encourage investment in human capital. The bulk of social policy programs falls into the middle category: social insurance. This helps to explain the widespread support welfare states enjoy: risk-averse citizens are willing to pay a price for insurance; the normative principle (C) The European Political Science Association 2019. 
underlying insurance is reciprocity (not empathy, as in Robin Hood style redistribution); and who wins and loses in the system is, to a certain degree, shrouded in uncertainty.

Whether someone will be a net-benefit winner or loser of a social policy program crucially depends on their risk and income. Simply put, risk-the probability of experiencing an event that is covered by a program-determines whether, how often, and how long, someone will receive a benefit. First, social insurance redistributes from low to high risks. Because social policy programs are typically financed through progressive taxation or contributions, income influences the costs of a benefit. Second, social insurance redistributes from high to low incomes. On balance, net beneficiaries can be expected to be strong supporters of the system, while net benefit losers can be expected to be less enthusiastic about them, although even they may be willing to support the system, as they are willing to pay a price for having insurance.

Most social policy programs are mandatory, pooling the risks, and incomes, of all citizens. Often, net benefit winners and net benefit losers are not easily identifiable ex ante (before a risk event happens), in which case social policy programs should enjoy broad support. This is less true, however, if risk is more unevenly distributed within a society (Rehm 2016); if risk profiles are better known ex ante; if income is more unevenly distributed; and if low income and high risk are more reinforcing rather than cross-cutting (Rehm, Hacker and Schlesinger 2012; Häusermann, Kurer and Schwander 2015). Simply put, welfare states thrive where risk and income are relatively evenly distributed, and where they do not overlap too strongly. In contrast, where risk and income inequality are high, and where these traits are reinforcing-the rich are also lucky, the poor are also unlucky-social policy will be contentious.

Several ongoing developments suggest that we are moving from conditions under which welfare states thrive to those under which they will come under intense pressure. Current technological and social changes will likely increase risk inequality; increase the predictability of risk; increase income and wealth inequality; and increase the overlap between income and risk. As a result, a plausible prediction is that intense polarization about social policy programs will replace their current broad appeal. We might even observe that a sizeable and economically and politically potent group of "insiders" will strive for exit from the common risk pool.

\section{The challenges}

\subsection{Pressure From Below: Labor Market Risks}

Several well-documented developments are likely to increase risk inequality, the predictability of risk, and the overlap of income and risk. In past decades, labor market development in advanced industrial societies experienced polarized job growth (Autor, Katz and Kearney 2006): only high-skilled and low-skilled jobs grew, while medium-skilled jobs disappeared. While ongoing and future technological change will affect all skill levels, it will substitute mainly medium- and especially low-skilled labor (Frey and Osborne 2017), increasing the gap between the top and the bottom. Furthermore, the remaining low-skilled jobs have little room for productivity improvements and hence wage increases (Baumwol's disease). Because of these developments, we can expect the emergence of a sizeable group of citizens that are "bad risks" ( permanent outsiders), with little prospect for improvement. The faiths of low- and high-skilled labor will be increasingly different and divorced.

If winners and losers are clearly identifiable ex ante, social insurance does not fare well. A sizeable group of low-skilled workers with no attractive job opportunities and very little upward mobility would be very visible, and it would require hammock-style social policy (permanent social assistance), which is unpopular. This puts pressure on existing social policy programs from below.

\subsection{Pressure From Above: Old-Age Risks}

Increasing income and wealth inequality will put pressure on redistributive social insurance systems from above: the wider the gap between the rich and the poor, the less attractive it is for the 
rich to be part of a mandatory risk pool, especially if they have sufficient resources to self-insure even significant bad events. There are many developments that are likely to increase income inequality. These include skill-biased technological change, which increases income inequality and decreases social mobility. Increasing assortative mating (particularly in combination with smaller families) reinforces that trend, especially since well-off families often aggressively invest in the human capital of their children. Wealth inequality is also likely to rise: Piketty (2014) has argued that returns on capital are generally higher than economic growth ( $r>g$ ). Assortative mating and small families mean that wealth holding patterns are reinforced over time because larger bequests are concentrated on fewer heirs.

Another trend may stealthily contribute to wealth inequality: the privatization of social policy risks-what Jacob Hacker (2008) calls the "the great risk shift"-especially with respect to pensions. All rich democracies have public (or mandatory private) pension programs of sorts, often complemented by (voluntary or mandatory, industry-wide or personal) alternative "pillars." Over the last three decades or so, pension reforms have generally been in the direction of less generous replacements rates (Immergut, Anderson and Schulze 2007; Häusermann 2010) and a shift from defined benefits (pay-as-you-go) to defined contributions (funded) ${ }^{1}$ pension systems (OECD 2017). This quiet development will put pressure from above on existing social policy programs, likely undermining social solidarity.

The reason is simple: if defined contribution pensions are small, private savings have to be very large in order to achieve a reasonably high standard of living in retirement. With some exceptions (such as survivor pensions), public pension entitlements expire with the death of the recipient. In contrast, private savings can be transferred to the next generation: in essence, the aggressive savings of one generation are equivalent to deferred consumption for the next generation. The inherited wealth may well be significant enough for the offspring to pay itself a private and fairly generous monthly stipend ("private basic income") to sustain a middle-class level standard of living, without participating in the labor market. ${ }^{2}$

In this scenario, a "private basic income" would offer the ability to self-insure regarding the labor market, education and pension risks, and take away incentives to support risk pooling in these social policy domains (health insurance may be the exception here, since self-insurance requires enormous private resources-see below). ${ }^{3}$ Furthermore, citizens that cannot self-insure are likely worse risks, which makes social insurance more expensive and less attractive. Welfare states may be heading toward a (social) insurance death spiral.

"Voluntary labor market outsiders" (those who can pay themselves a sizeable private basic income) have always existed. However, the increasing importance of private pensions could be a real game changer, for various reasons. First, the phenomenon is systematic-aggressively building up wealth holdings is increasingly not a choice, but a requirement. Even parents who do not intend to leave a large inheritance have to do so, for reasons of self-interest. Second,

\footnotetext{
${ }^{1}$ Defined benefits and pay-as-you go systems on the one hand, and defined contribution and funded systems are not the same thing, although they typically go hand in hand.

${ }^{2}$ Here is a back-of the envelope example. Let us say there are two working parents making a combined 10,000 (net) per month, for about 30 years $(10,000 \times 12 \times 30=3,600,000)$. They want to retire at 5000 (though most people would define "comfortable" at about 70 percent of your earnings, i.e., 7000 in the example), and they anticipate being in retirement for 30 years. Depending on a variety of uncertain parameters (return on investment, life expectancy, and so on), the parents will need to save up about 1-2 million, or about roughly half of their income. Typically, one would buy an annuity for about half of the savings, and leave the other half as principal (so that is 500,000-1 million). The (typically) only child will inherit that principal (plus, in the above scenario, likely also a house), and this bequest is at best mildly taxed. If s/he decides to, the offspring could pay herself about 3000-4000/month, forever (largely tax-free, and certainly contribution free) - not bad, especially if you do not pay rent.

${ }^{3}$ There are already examples of how the rich can opt out of risk pooling. In the United States, for example, "only" the first $\sim 128,000$ is taxed with Social Security contributions (the so-called wage base)-clearly a way for the rich and wealthy to opt out of the old-age risk pool.
} 
the phenomenon will be pervasive: the described dynamics could lead to a situation where a significant share of a future generation will be able to self-insure. Third, the phenomenon could lead to a very consequential bifurcation into those that have to participate in labor markets, and those who have a choice to do so or not.

\subsection{Potential Common Ground: Health Risks}

The inequality and predictability of risk may increase not only with respect to labor market risks (as discussed above), but also when it comes to other social policy risk, most importantly health-related risks. At the moment, health risks are still relatively unpredictable and relatively randomly distributed (which is fertile ground for widespread support for risk pooling). But the information revolution and advances in medical technology (such as genome-based prediction of diseases) could change the status quo (Iversen and Rehm 2016). In the not too distant future, it may well be possible to predict the future health of individuals, in which case people would know, ex ante, whether they are good or bad medical risks. In such a scenario, good health risks would have little incentive to pool with bad risks, especially if they have attractive private insurance options. Furthermore, it may well be that these types of advances also increase the predictability of longevity, with potential consequences for pension politics: being part of a mandatory public pension system is a lot more attractive for those with high longevity. ${ }^{4}$ The political consequences of this (anticipated) increased predictability and inequality in health risk are difficult to predict: much depends on whether health risks will correlate highly with socio-economic characteristics or not. It may be easier to maintain social solidarity in the health domain, compared with the labor market and pension domain.

\section{Solutions?}

The described dynamics would split future generations into three groups. One group has to participate in labor markets, with little prospect of holding a desirable job or upward mobility. A second group also has to participate in labor markets, but with good jobs and mobility prospects. And a third group of those who have a choice to participate in labor markets or not (those with private basic incomes). This, in no sense, would resemble equality of opportunity or meritocracy. It would also put enormous pressure on existing social insurance arrangements.

What, if anything, could be done to deal with this scenario? Most of the developments sketched out above are structural in nature; policies may slow the speed of change, but they are unlikely to stop the trends. This is not to say that nothing can be done. It is time to think about systemic changes to welfare states that could significantly relieve the pressure-from below and above-social policy programs will experience.

Some favor replacing (most) social policy programs with an unconditional, flat-rate basic income for all citizens (Parijs 1997). This proposal is by no means uncontested (Fitzpatrick and Campling 1999), but the basic income idea has the potential to ameliorate some of the problems discussed above. Perhaps most importantly, it would level the playing field in terms of labor supply: participating in the labor market would become optional for everybody, not just for those who can afford a private basic income. There would still be large inequalities in income and wealth, but a basic income would allow citizens without resources to take risks that could pay off and make them upwardly mobile. A basic income, which is unconditional and paid to every citizen, would also offer a livelihood for "permanent outsiders," without the stigma (and discourses of deservingness) that are typical of means-tested programs. Aggressive inheritance taxation could reinforce the positive effects of a basic income by curbing the increasing inequality in financial resources.

\footnotetext{
${ }^{4}$ If longevity and health risks were positively correlated (e.g., because medical risks increase in age), one could envision some logrolling between bad health risks with low longevity and good health risks with high longevity: I pool my health risks with you if you pool your longevity risk (pensions) with me.
} 
However, we cannot do without a comprehensive mandatory health insurance system that pools the risks of all citizens. One attraction of the basic income is its simplicity: it replaces all other social policy efforts, thereby de-cluttering welfare states and their bureaucracies. One problem of the basic income is that it does not provide adequate insurance against health risks: disability, chronic, or expensive diseases cannot be shouldered with an unconditional, flat-rate monthly stipend. Therefore, the basic income needs to be coupled with mandatory health insurance in which premiums are not linked to risks. Fortunately, there are reasons to believe that it will remain attractive for the vast majority to continue pooling health risks, making it easier to sustain or build a broad coalition in support of mandatory health insurance systems. This would be particularly true if "pulling the veil of ignorance" regarding health risks is tightly regulated (no scaling of premiums based on DNA, etc.).

The scholarship on labor market inequalities and their political consequences has identified and documented many challenges to existing welfare states. However, in the main, welfare state contestation has remained a matter of degree. In the future, in contrast, the key conflict regarding social policy will not be "more or less" but "whether or not." We do not know whether the developments sketched above-skill-biased technological change, privatization of pensions, higher rates of assortative mating, the information revolution-will lead to majority support for radical changes to the status quo. But there are good reasons to believe that welfare state politics will qualitatively change in the future.

Acknowledgments. The authors wish to thank Silja Häusermann, Achim Kemmerling, and David Rueda for their helpful comments.

\section{References}

Autor DH, Katz LF, and Kearney MS (2006) The Polarization of the U.S. Labor Market. The American Economic Review, 96, 189-94. Fitzpatrick T, and Campling J (1999) Freedom and Security: An Introduction to the Basic Income Debate. London: Palgrave Macmillan.

Frey CB, and Osborne MA (2017) The Future of Employment: How Susceptible are Jobs to Computerisation? Technological Forecasting and Social Change, 114:254-280.

Hacker JS (2008) The Great Risk Shift: The New Economic Insecurity and the Decline of the American Dream, 2nd ed. New York: Oxford University Press.

Häusermann S (2010) The Politics of Welfare State Reform in Continental Europe: Modernization in Hard Times. Cambridge, MA: Cambridge University Press.

Häusermann S, Kurer T, and Schwander H (2015) High-Skilled Outsiders? Labor Market Vulnerability, Education and Welfare State Preferences. Socio-Economic Review, 13, 235-258.

Immergut EM, Anderson KM, and Schulze I (2007) The Handbook of West European Pension Politics. Oxford: Oxford University Press.

Iversen T (2005) Capitalism, Democracy, and Welfare. Cambridge, MA: Cambridge University Press.

Iversen T, and Soskice D (2001) An Asset Theory of Social Policy Preferences. American Political Science Review, 95, 875-895.

Iversen T, and Rehm P (2016) 'The Market for Cream Puffs: Big Data and the Transformation of the Welfare State'. Unpublished manuscript.

OECD. (2017) Pension Markets in Focus 2017. Paris: OECD.

Parijs Philippe van (1997) Real Freedom for All: What (If Anything) Can Justify Capitalism? Oxford: Oxford University Press.

Piketty T (2014) Capital in the Twenty-First Century. Cambridge: Harvard University Press.

Rehm P (2016) Risk Inequality and Welfare States. Social Policy Preferences, Development, and Dynamics. Cambridge, MA: Cambridge University Press.

Rehm P, Hacker JS, and Schlesinger M (2012) Insecure Alliances: Risk, Inequality, and Support for the Welfare State. American Political Science Review, 106, 386-406.

Rueda D (2005) Insider-Outsider Politics in Industrialized Democracies: The Challenge to Social Democratic Parties. American Political Science Review, 99, 61-74.

Rueda D (2007) Social Democracy Inside Out: Partisanship and Labor Market Policy in Advanced Industrialized Democracies. Oxford: Oxford University Press.

Cite this article: Rehm P (2020). The Future of Welfare State Politics. Political Science Research and Methods 8, 386-390. https://doi.org/10.1017/psrm.2018.33 